\title{
Gram-negative Septicemia after Infliximab Treatment in an Infant with Refractory Kawasaki Disease
}

\author{
Jin Hwan Lee, M.D., Jung Min Yoon, M.D., Jae Woo Lim, M.D., \\ Kyong Og Ko, M.D., Ph.D., and Eun Jung Cheon, M.D. \\ Department of Pediatrics, Konyang University College of Medicine, Deajeon, Korea
}

\begin{abstract}
Kawasaki disease (KD) is an immune-mediated disease which is a leading cause of acquired cardiovascular disease in developed country. Recently, tumor necrosis factor-alpha (TNF-alpha) blocker, infliximab has been considered a promising option for patients with refractory KD. Although chronic use of a TNF-alpha blocker could increase risk of opportunistic infections, a few studies have documented that use of infliximab was safe without serious adverse effects in patients with KD. We observed serious bacterial infection after infliximab treatment in an infant with refractory KD. Our patient was a 5-month-old male infant diagnosed with KD who did not respond to repeated doses of intravenous immunoglobulin. We effectively treated him with a single infusion of infliximab $(5 \mathrm{mg} / \mathrm{kg})$, but gram-negative (Acinetobacter Iwoffii) septicemia developed after infliximab infusion. Therefore, we report a case of serious septicemia after treatment with infliximab, and suggest considering the risk of severe infection when deciding whether to prescribe infliximab to an infant with refractory KD.
\end{abstract}

Key Words: Kawasaki disease, Tumor necrosis factor-alpha, Infliximab, Septicemia

\section{Introduction}

Kawasaki disease (KD) is an acute febrile disease of unknown etiology, characterized by systemic vascular inflammation involving the small- and mediumsized arteries, with a predilection for the coronary arteries $^{1)}$. Intravenous immunoglobulin (IVIG) infusion is an effective therapy for acute $\mathrm{KD}$, as it reduces the duration of fever and the prevalence of

\footnotetext{
*The authors have no conflicts of interest relevant this article to disclose.

Receiced: 21 July 2014, Revised: 28 August 2014

Accepted: 1 September 2014

Correspondence: Eun Jung Cheon, M.D.

Department of Pediatrics, Konyang University College of Medicine, Daejeon, Korea

Tel : +82-42-600-9230, Fax : +82-42-600-9090

E-mail : ejcheon000@kyuh.ac.kr
}

coronary artery aneurysms ${ }^{2)}$. Nevertheless, approximately $10 \%$ of patients are refractory to IVIG treatment; refractory $\mathrm{KD}$ is defined as persistent fever of $\geq 38.5^{\circ} \mathrm{C}$ for 36 hours after initial IVIG treatment ${ }^{3)}$. These patients are in need of additional therapy, such as repeated doses of IVIG or pulse methylprednisolone ${ }^{4,5)}$.

Recently, infliximab, tumor necrosis factor-alpha (TNF-alpha) blocker, has also been considered a promising option for patients with refractory $\mathrm{KD}^{6)}$. Although chronic use of a TNF-alpha blocker might increase the risk of opportunistic infections ${ }^{7)}$, a few studies have documented that the use of infliximab was safe, without serious adverse effects, in patients with $\mathrm{KD}$ refractory to $\mathrm{IVIG}^{8,9)}$. However, we observed a case of gram-negative septicemia that developed after infliximab treatment in a 5 -month- 
old infant with refractory $\mathrm{KD}$.

\section{Case Report}

A 5-month-old male infant with body weight of $5.7 \mathrm{~kg}$ (<3rd percentiles) and height of $63 \mathrm{~cm}(10-$ 25th percentiles), was admitted because of high fever up to $40^{\circ} \mathrm{C}$ developed at two days prior to admission. He was born at 36(+6) gestational weeks with birth weight of $2 \mathrm{~kg}$. He had been small for gestational age because of maternal hypertension. Physical examination revealed bilateral non-exudative conjunctival injection, red cracked lips, strawberry tongue, subcutaneous edema, erythema of hands and feet, erythema at the BCG site, and erythematous maculopapular rashes on the trunk and extremities. Laboratory tests showed the following results (1st hospital day [HD]): white blood cell (WBC) count 39,200 cells/uL (segmented neutrophils 77\%, lymphocytes 20\%), hemoglobin (Hb) $10.9 \mathrm{~g} / \mathrm{dL}$, hematocrit (Hct) $32.1 \%$, platelet count 466,000 cells/ $\mu \mathrm{L}$, erythrocyte sedimentation rate (ESR) $61 \mathrm{~mm} / \mathrm{h}$, C-reactive protein (CRP) $16.5 \mathrm{mg} / \mathrm{dL}$, albumin 4.0 $\mathrm{g} / \mathrm{dL}$, protein $6.29 \mathrm{~g} / \mathrm{dL}$, asparatate aminotransferase/ alanine aminotransferase (AST/ALT) 34/17 IU/L, and $\mathrm{N}$-terminal fragment of prohormone $\mathrm{B}$-type natriuretic peptide (NT-proBNP) $1,040 \mathrm{pg} / \mathrm{mL}$ (Table 1). Urinalysis showed $10-20 \mathrm{WBC}$ per high power field. No respiratory virus was identified in the common respiratory virus polymerase chain reaction (RV-PCR) test. The results of initial blood and urine cultures were unremarkable. We performed echocardiography, which revealed an aneurysm of $5 \mathrm{~mm}$ in diameter at the left main coronary artery.

His fever persisted despite treatment with IVIG (2 g/kg; 2nd HD) and aspirin (50 mg/kg/day); therefore, we administered a second dose of IVIG ( $2 \mathrm{~g} /$ $\mathrm{kg}$; 4th HD). He was also treated with empirical antibiotic (ampicillin/sulbactam) from the 1st to the 12 th day after admission. Nevertheless, the patient remained febrile, and other symptoms of $\mathrm{KD}$ persisted. The follow-up laboratory examination (5th HD) showed the following results: WBC count 12,800 cells/uL (segmented neutrophils $49 \%$, lymphocytes 37\%), Hb 9.2 g/dL, Hct 28\%, ESR 69 mm/h, CRP $18.1 \mathrm{mg} / \mathrm{dL}$, albumin $2.4 \mathrm{~g} / \mathrm{dL}$, protein $7.5 \mathrm{~g} / \mathrm{dL}$, AST/ALT 18/45 IU/L, NT-proBNP 3,066 pg/mL, blood urea nitrogen (BUN) $2.6 \mathrm{mg} / \mathrm{dL}$ and creatinine (Cr) $0.35 \mathrm{mg} / \mathrm{dL}$. Echocardiography revealed a $5-$ $\mathrm{mm}$ fusiform dilatation in the proximal lesion of the

Table 1. Clinical Course of the Laboratory Findings

\begin{tabular}{|c|c|c|c|c|c|c|c|c|c|c|}
\hline Day & $\begin{array}{c}\text { WBC } \\
\text { (cells/uL) }\end{array}$ & $\begin{array}{l}\text { Seg. } N \\
(\%)\end{array}$ & $\begin{array}{l}\mathrm{Hb} \\
(\mathrm{g} / \mathrm{dL})\end{array}$ & $\begin{array}{l}\text { Platelet } \\
\text { (cells/ } / \mu \mathrm{L})\end{array}$ & $\underset{(\mathrm{g} / \mathrm{dL})}{\text { Albumin }}$ & $\begin{array}{l}\text { AST } \\
\text { (IU/L) }\end{array}$ & $\begin{array}{c}\text { ALT } \\
\text { (IU/L) }\end{array}$ & $\begin{array}{c}\text { CRP } \\
(\mathrm{mg} / \mathrm{dL})\end{array}$ & $\begin{array}{c}\text { ESR } \\
(\mathrm{mm} / \mathrm{h})\end{array}$ & $\begin{array}{c}\text { NT-proBNP } \\
(\mathrm{pg} / \mathrm{mL})\end{array}$ \\
\hline \multicolumn{11}{|c|}{ Initial admission } \\
\hline 1 & 39,200 & 77 & 10.9 & 466,000 & 4 & 34 & 17 & 16.5 & 61 & 1,040 \\
\hline 5 & 12,800 & 49 & 9.2 & 331,000 & 2.4 & 18 & 45 & 18.1 & 69 & 3,066 \\
\hline 17 & 16,700 & 26.1 & 8.8 & 995,000 & 3.7 & 42 & 48 & 0.2 & 49 & 388 \\
\hline \multicolumn{11}{|c|}{ Readmission } \\
\hline 1 & 24,700 & 48.1 & 9.2 & 660,000 & 3.8 & 27 & 18 & 3.9 & 42 & \\
\hline 5 & 28,100 & 30 & 9.4 & 606,000 & 3.3 & 26 & 16 & 12.3 & 68 & \\
\hline 9 & 16,700 & 34.2 & 9.5 & 698,000 & 3.7 & 46 & 31 & 0.8 & 45 & \\
\hline
\end{tabular}

Abbreviations: WBC, white blood cell; Seg. N, segmented neutrophil; Hb, hemoglobin; AST, asparatate aminotransferase; ALT, alanine aminotransferase; CRP, C-reactive protein; ESR, erythrocyte sedimentation rate; NT-proBNP, N-terminal fragment of prohormone $\mathrm{B}$-type natriuretic peptide. 
left anterior descending (LAD) artery, entire tubular dilatation in the other coronary arteries, and trivial mitral regurgitation. He was diagnosed with refractory $\mathrm{KD}$ and we decided to perform the treatment with a single infusion of infliximab $(5 \mathrm{mg} / \mathrm{kg}$ ) (7th $\mathrm{HD})$. All symptoms of $\mathrm{KD}$, including fever, improved within 48 hours after infliximab infusion. The patient was discharged on low-dose aspirin at the seventeenth day of illness. At five days after discharge, he was readmitted because of abrupt onset of high fever, mild generalized edema, and poor urination without any other respiratory symptoms. The patient showed lethargic and edematous appearance; his blood pressure was $80 / 50 \mathrm{mmHg}$, and his pulse rate was 130 beats/min. Laboratory investigations (1st

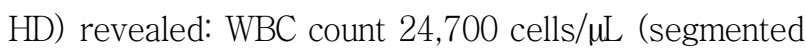
neutrophils $48.1 \%$, lymphocytes $34.1 \%$ ), Hb 9.2 g/ dL, Hct 28.2\%, platelet count 660,000 cells/ $\mu \mathrm{L}, \mathrm{ESR}$ $42 \mathrm{~mm} / \mathrm{h}$, CRP $3.9 \mathrm{mg} / \mathrm{dL}$, albumin $3.8 \mathrm{~g} / \mathrm{dL}$, protein 7.5 g/dL, AST/ALT 27/18 IU/L, BUN/Cr 15.7/0.46 $\mathrm{mg} / \mathrm{dL}$. Urinalysis was clear, and a chest radiogram was unremarkable. Echocardiographic findings were similar to those from the previous examination. We prescribed intravenous antibiotic (ampicillin/sulbac- tam) from the 1st day of readmission. Nevertheless, the patient had persistent spiking fever and remained lethargic and edematous appearance. On the fifth day of readmission, CRP level was increased up to $12.3 \mathrm{mg} / \mathrm{dL}$, and the initial a couple of blood cultures showed the presence of Acinetobacter lwoffii, which was susceptible to cefotaxime, gentamicin, and imipenem. We promptly administered cefotaxime according to the results of the blood culture. On the seventh day of readmission, the patient's fever gradually subsided, and his general condition recovered. A follow-up blood culture was subsequently negative. The patient was treated with appropriate antibiotics for two weeks and then discharged (Fig. 1). Three months later, we consulted a pediatric immunologist for evaluation of his immunologic function, and all immunologic tests were normal. Therefore, we assumed that our patient's gram-negative septicemia might be associated with infusion of infliximab, based on his previous history of treatment with an immunosuppressant agent, clinical findings such as a spiking fever, lethargy, oligouria, and hypotension, positive blood cultures, and dramatic improvement of symptoms including fever after treatment with an

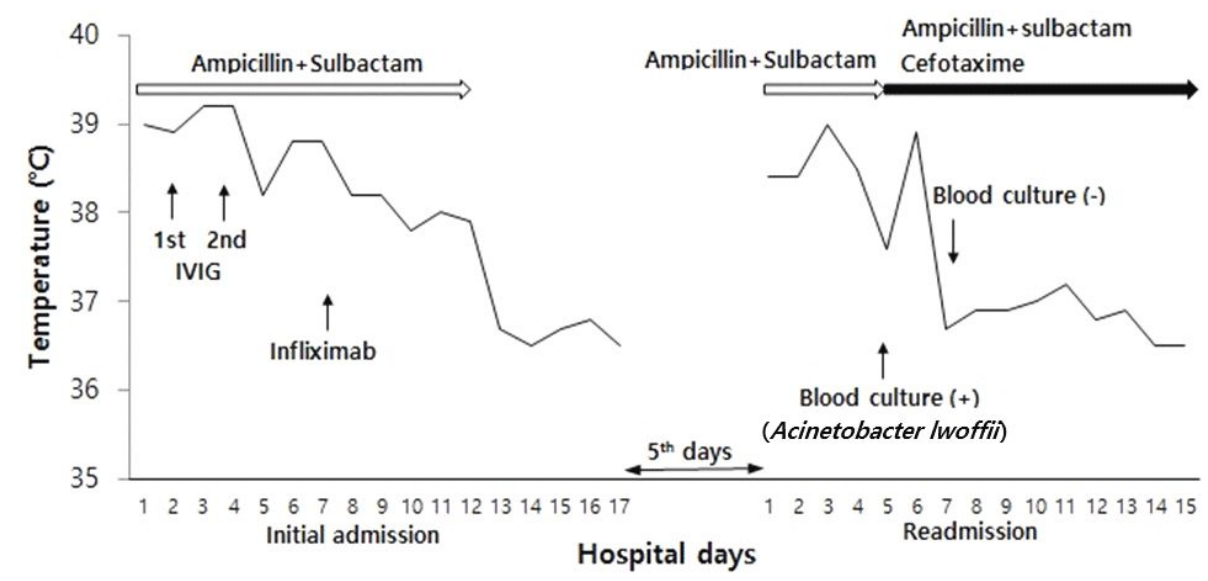

Fig. 1. Changes in the body temperature and the types of interventions used during the hospital course. 
antibiotic susceptible to $A$. Iwoffii.

\section{Discussion}

Standard treatment of KD with IVIG and high-dose aspirin is highly effective ${ }^{2)}$; 80-90\% of patients show disease remission. Unresponsiveness to IVIG has been considered a major risk factor for the development of coronary artery lesions ${ }^{3)}$. Recently, it has been suggested that pulse methylprednisolone ${ }^{5)}$ and second line treatments, such as infliximab and methotrexate $^{10)}$, may be used for children with $\mathrm{KD}$ who fail to respond to a repeated doses of IVIG.

TNF-alpha blockers have been shown to be effective immunosuppressive therapy in most children and adolescents with refractory Crohn's disease (CD) 11). As well, TNF-alpha and TNF-alpha soluble receptors I and II concentrations increase in the acute phase of $\mathrm{KD}$, and they are the highest in children who subsequently develop coronary artery aneurysms $^{12)}$. Infliximab neutralizes the biological activity of TNF-alpha by binding with high affinity to the soluble and transmembrane forms of TNF-alpha. Neutralization of the biological activity of TNF-alpha leads to an overall reduction in inflammation. So infliximab administration can be a very important rescue medication for children with refractory $\mathrm{KD}^{9}$, 13). Mori et al. described a case series in which 18 of 20 patients were effectively treated with infliximab to prevent progression to coronary artery lesions, without any adverse events ${ }^{14)}$.

Infliximab inhibits the binding of TNF-alpha and its receptors, and it subsequently reduces production of pro-inflammatory cytokines, such as interleukins 1 and 6 . As a result, this limits leukocyte migration and expression of adhesion molecules by endothelial cells and leukocytes. Infliximab also limits the activation of neutrophil and eosinophil functional activity and interferes with the production of cytotoxic metabolites by macrophages, thereby decreasing phagocytic killing activity. Surface-bound TNF-alpha is likely to be involved in cell-to-cell interactions, possibly potentiating the activation of specific and non-specific immune effective cells ${ }^{15)}$. Given the complex cytokine interactions and the multiple cytokine targets, infliximab-associated immunomodulation is very likely to lead to a higher risk of severe infections. It has been noted that chronic use of a TNF-alpha blocker over months to years was associated with an increased risk of infections with mycobacteria and fungi ${ }^{16,17)}$. Furthermore, Kroesen et al. documented that disseminated infections may give rise to serious bacterial infections from both gram-positive and gram-negative microorganisms in patients with rheumatoid arthritis who received anti-TNF-alpha therapy ${ }^{18)}$. A case report described an adult patient with $\mathrm{CD}$ receiving infliximab who experienced pulmonary infection due to Acinetobacter species, diagnosed via quantitative sputum cultures, along with another gram-negative infection ${ }^{19)}$. However, although a few studies reported that single infusions of infliximab were not associated with severe infection in any infants with $\mathrm{KD}^{9)}$, complications caused by a single dose of infliximab have not been clearly documented.

Generally, while the effectiveness of antibiotic use is not clear, a previous study demonstrated that $\mathrm{KD}$ is associated with marked activation of monocyte/macrophages and the selective expansion of $\mathrm{V}$ $\beta 2$ - and, less so, of Vß8.1/8.2-expressing T cells in the peripheral blood from $\mathrm{KD}$ patients during the acute phase of their illness. These immunologic fea- 
tures are characteristic of diseases that are caused by bacterial toxins, which act as superantigens ${ }^{20)}$. In other respects, there is a possibility that bacterial infection caused by immunomodulation during and after treatment with infliximab can occur. In our case, we administered an antibiotic empirically during treatment with infliximab; however, they were ineffective against $A$. lwoffii. Therefore, we could not prevent the development of septicemia caused by A. lwoffii. For that reason, we suppose that administration of appropriate antibiotics not only can help prevent $\mathrm{KD}$, which might be triggered by bacterial infection, but can also help prevent septicemia after infliximab treatment.

Our patient, a 5-month-old male infant with $\mathrm{KD}$, failed to defervesce despite repeated doses of IVIG. Therefore, a single infusion of infliximab $(5 \mathrm{mg} / \mathrm{kg}$ ) was administered on the seventh day of illness; his fever and other systemic symptoms promptly resolved within 2 days. However, within 2 weeks after treatment with infliximab, he was diagnosed with $A$. lwoffii septicemia, having clinical symptoms such as a spiking fever, lethargy, oligouria, and hypotension. A. lwoffii is an immotile, aerobic gram-negative coccobacillus that has become important in nosocomial infections, mostly involving patients with impaired host defense. Although differentiation between blood specimen contamination by skin inhabitants and true bacteremia is sometimes rather difficult, significant bacteremia caused by Acinetobacter species is highest rate of nosocomial bacteremia occurring during the second week of hospitalization. Especially, it is well known that Acinetobacter spp. is considered to be organisms capable of causing severe nosocomial infection in neonatal intensive care units ${ }^{21)}$. Regrettably, we did not perform immunologic tests in our patient, but we consulted a pediatric immunologist in another hospital, and his investigations revealed that the patient's immunologic function was competent. Our patient experienced septicemia within 2 weeks after an infusion of infliximab. Bruns et al. documented that infliximab-medicated deletion of $\mathrm{T}$ cells persists for 2 weeks after initiating therapy 22). Furthermore, our patient's clinical symptoms, including a fever, resolved dramatically after treatment with an antibiotic to which $A$. lwoffii was susceptible, according to the results of the microbiological sensitivity tests. Considering the above reasons, we speculate that gram-negative septicemia in our patient may have been associated with the use of infliximab. Therefore, we suggest that patients, especially infants or young children, should be closely monitored for signs and symptoms of infection during and after treatment with infliximab, including the possible development of serious infections.

\section{한 글 요 약}

\section{불응성 가와사키병 환아에서 infliximab 사용 후 발생한 패혈증}

건양대학교 의과대학 소아과학교실

\section{이진환 · 윤정민 · 임재우 · 고경옥 · 천은정}

최근 가와사키병에서 tumor necrosis factor-alpha (TNF-alpha) blocker인 infliximab 단일 정주 요법이 불응성 가와사키병 환자들에게 유용한 치료제로 여겨지 고 있다. 장기적인 TNF-alpha blocker 사용이 기회감염 의 위험을 증가시킬 수 있지만, 가와사키병 환자들에게 infliximab 사용이 심각한 부작용을 초래하지 않으며 안 전하게 사용된 증례들이 보고된 바 있다. 불응성 가와사 키병을 않고 있는 5 개월 된 영아에서 infliximab (5 mg/ 
$\mathrm{kg}$ ) 단일 정주 요법을 사용하였고 가와사키 증상이 호전 되었으나 infliximab 치료 후 Acinetobacter lwoffii에 의한 패혈증이 발생하였다. 그래서 저자들은 불응성 가와 사키병을 않은 영아에서 infliximab 치료 후 발생한 패혈 증의 첫 사례를 보고하며 infliximab 치료 선택에 있어 기 회 감염의 위험성에 대해 고려할 것을 당부하는 바이다.

\section{References}

1) Melish ME. Kawasaki syndrome. Pediatr Rev 1996;17: 153-62.

2) Newburger JW, Takahashi M, Burns JC, Beiser AS, Chung KJ, Duffy CE, et al. The treatment of Kawasaki syndrome with intravenous gamma globulin. N Engl J Med 1986;315:341-7.

3) Burns JC, Capparelli EV, Brown JA, Newburger JW, Glode MP. Intravenous gamma-globulin treatment and retreatment in Kawasaki disease. US/Canadian Kawasaki Syndrome Study Group. Pediatr Infect Dis J 1998;17: 1144-8.

4) Sundel RP, Burns JC, Baker A, Beiser AS, Newburger JW. Gamma globulin re-treatmetn in Kawasaki disease. J Pediatr 1993;123:657-9.

5) Furukawa T, Kishiro M, Akimoto K, Nagata S, Shimizu T, Yamashiro Y. Effects of steroid pulse therapy on immunoglobulin-resistant Kawasaki disease. Arch Dis Child 2008;93:142-6.

6) Burns JC, Mason WH, Hauger SB, Janai H, Bastian JF, Wohrley JD, et al. Infliximab treatment for refractory Kawasaki syndrome. J Pediatr 2005;146:662-7.

7) Bongartz T, Sutton AJ, Sweeting MJ, Buchan I, Matteson EL, Montori V. Anti-TNF antibody therapy in rheumatoid arthritis and the risk of serious infections and malignancies: systematic review and meta-analysis of rare harmful eff ects in randomized controlled trials. JAMA 2006;295:2275-85.

8) Yu HJ, Lee SJ, Sohn S. Infliximab treatment for a patient with refractory Kawasaki disease. Korean J Pediatr 2006; 49:987-90.

9) Adriana H, Tremoulet, Sonia J. Infliximab for intensification of primary therapy for Kawasaki disease: a phase 3 randomised, double-blind, placebo-controlled trial. The Lancet 2014;83:1731-8.

10) Shin JI, Lee JS, Choi JY, Kim DS, Girish M, Subramaniam. Refractory Kawasaki disease: infliximab or methotrexate therapy? Indian J Pediatr 2009;76:1184.

11) Parashette KR, Makam RC, Cuffari C. Infliximab therapy in pediatric Crohn's disease: a review. Clin Exp Gastroenterol 2010;3:57-63.

12) Matsubara $T$, Furukawa $S$, Yabuta K. Serum levels of tumor necrosis factor, interleukin 2 receptor, and interferon-gamma in Kawasaki disease involved coronaryartery lesions. Clin Immunol Immunopathol 1990;56: 29-36.

13) Burns JC, Best BM, Mejias A, Mahony L, Fixler DE, Jafri HS, et al. Infliximab treatment of intravenous immunoglobulin-resistant Kawasaki disease J Pediatr 2008; 153:833-8.

14) Mori M, Imagawa $T$, Hara $R$, Kikuchi $M$, Hara $T$, Nozawa T, et al. Efficacy and limitation of infliximab treatment for children with Kawasaki disease intractable to intravenous immunoglobulin therapy: report of an open-label case series. J Rheumatol 2012;39:864-7.

15) Maini RN, Taylor PC. Anti-cytokine therapy for rheumatoid arthritis. Annu Rev Med 2000;51:207-29.

16) Miyamoto H, Miura $T$, Morita E, Morizaki $Y$, Uehara $\mathrm{K}$, Ohe $\mathrm{T}$, et al. Fungal arthritis of the wrist caused by Candida parapsilosis during infliximab therapy for $\mathrm{rheu}^{-}$ matoid arthritis. Mod Rheumatol 2012;22:903-6.

17) Keane J, Gershon S, Wise RP, Mirabile-Levens E, Kasznica J, Schwieterman WD, et al. Tuberculosis associated with infliximab, a tumor necrosis factor alpha-neutralizing agent. N Engl J Med 2001;345:1098-104.

18) Kroesen S, Widmer AF, Tyndall A, Hasler P. Serious bacterial infections in patients with rheumatoid arthritis under anti-TNF-alpha therapy. Rheumatology (Oxford) 2003;42:617-21.

19) Stratakos G, Kalomenidis I, Papas V, Malagari K, Kollintza A, Roussos C, et al. Cough and fever in a female with Crohn's disease receiving infliximab. Eur Respir J 2005;26:354-7.

20) Leung DY, Meissner C, Fulton D, Schlievert PM. The potential role of bacterial superantigens in the pathogenesis of Kawasaki syndrome. J Clin Immunol 1995;15: 11S-7S.

21) Bergogne BE, Towner K. Acinetobacter spp. as nosocomial pathogens: Microbiological, clinical, and epidemiologic features. Clin Microbiol Rev 1996;9:148-65.

22) Bruns H, Meinken C, Schauenberg P, Harter G, Kern $\mathrm{P}$, Modlin RL, et al. Anti-TNF immunotherapy reduces CD8+ $\mathrm{T}$ cell-mediated antimicrobial activity against Mycobacterium tuberculosis in humans. J Clin Invest 2009;119:1167-77. 